Reprod. Nutr. Dévelop. 1980, 20 (1 A), 183-190.

\title{
Feulgen-DNA changes in the germ cells of the male vole (Microtus agrestis) during their development
}

\author{
par J. R. CLARKE *, C. ESNAULT, J.-C. NICOLLE \\ Laboratoire de Physiologie de la Reproduction, I.N.R.A. \\ Nouzilly, 37380 Monnaie, France. \\ * Department of Agriculfural Science, University \\ of Oxford, OXI 3PF England.
}

\begin{abstract}
Summary. Consistent with changes in ploidy during germ cell maturation, the quantity of Feulgen DNA in round spermatids of voles is approximately a quarter of that in primary spermatocytes. The amount increases slightly in elongated spermatids, and then declines in spermatozoa from the testis, epididymis and vas deferens, below the level of round spermatids. Simultaneously nuclear area decreases so that in spermatozoa it is about one tenth that of primary spermatocytes. The rise in Feulgen DNA in elongated spermatids above the level found in round spermatids, and the decline in spermatozoa below this level, is probably caused by altered affinity of the desoxyribose for the leucofuchsin. This may be brought about by the complex physico-chemical changes occurring in chromatin and elsewhere in the nucleus and cell as they acquire their highly specialised final form.
\end{abstract}

\section{Introduction.}

In the bull, ram and rabbit U-V DNA and Feulgen DNA values drop fourfold as primary spermatocytes transform through secondary spermatocytes to round spermatids. In the development of spermatids into mature spermatozoa (such as those in the vas deferens or in an ejaculate), it has been shown in these 3 species that there is no further change in the U-V DNA, whereas there is a statistically significant additional decline in the Feulgen DNA (Gledhill ef al., 1966 ; Bouters ef al., 1967a, b ; Courot ef al., 1970 ; Esnault and Nicolle, 1976). In rams maintained on long (as opposed to short) photoperiods, there is considerable degeneration of germ cells, particularly during meiosis. The primary spermatocytes and spermatids of such sheep have less Feulgen DNA than those of sheep on short photoperiods. This alteration in Feulgen DNA may hold in it a clue to the cause of germ cell degeneration (Esnault ef al., 1964). Testis activity in the vole (Microtus agrestis) is markedly affected by photoperiod. Qualitative and quantitative studies have already been made of spermatogenesis in voles living in long photoperiods which are favourable, and short photoperiods which are unfavourable, for vole testicular function (Grocock and Clarke, 1974, 1975, 1976). As with the sheep, photoperiods unfavourable for vole festicular function cause consi- 
derable loss of germ cells, particularly during meiosis. The vole might prove a useful experimental animal for the further study of the maturation of spermatozoa, including the factors determining germ cell loss during spermatogenesis. For this reason an investigation has been made of their Feulgen DNA.

\section{Material and methods.}

Sexually mature voles came from the colony maintained in the Department of Agricultural Science, Oxford, under constant conditions of lighting (16 L : $8 \mathrm{D}$ per day) and temperature $\left(18^{\circ} \mathrm{C}\right)$. They were killed with ether vapour. Two types of preparation of germ cells were made from each of 7 voles.

1. Testis imprints. A freshly dissected testis was cut in half, and an exposed surface allowed gently to touch a chemically clean, dust-free, glass microscope slide. From a cut surface 6 to 12 such imprints were made on each of several slides. Such preparations proved to be essentially monolayers of germ cells.

2. Smears from epididymis and vas deferens. Under a dissecting microscope small portions from the head, body and tail of epididymis, and from half way along the vas deferens, were dissected free of fat, each placed on its own chemically clean, dust-free, glass microscope slide in a drop of mammalian Ringer solution, and minced with fine scissors. The macroscopically visible surplus tissue was removed from the slide and, with a clean cover slip, a smear was made of the drop of fluid in the same way as blood smears are prepared. Several slides were made for each of the four parts of the male genital tract which were sampled. Immediately after being prepared the imprints and smears were fixed for $15 \mathrm{~min}$ in formaldehyde vapour. After fixation, slides were stored in chemically clean, closed, slide jars.

Slides were stained by the Feulgen reaction method described by Bouters ef al., $1967 a$, modified by Esnault and Nicolle (1976). Measurement of total extinction was at $560 \mathrm{~nm}$ using a Zeiss microspectrophotometer (UMSP1) connected to an XD50 digital scanning attachment by which an integrated value for total extinction of each nucleus was obtained. Simultaneously the area of each nucleus was measured by the instrument. The values for total extinction are expressed in arbitrary units proportional to the nuclear content of DNA. Using a set of standard slides of vole spermatozoa, optimum time for the acid hydrolysis in the Feulgen reaction, and for coloration with Feulgen solution, was first determined. In all batches of slides, comprising all for one or more animals, an additional slide not submitted to acid hydrolysis, was examined to determine whether there was any non-specific coloration. In those few cases where such staining occurred, a fresh solution of Feulgen reagent was prepared, and a further set of slides stained. Thus measurements were only made on cells for which there was this assurance of stain specificity.

In imprints of testes, total extinction and area were measured for pachytene primary spermatocytes, secondary spermatocytes, round spermatids, elongated spermatids and spermatozoa. In the smears of the 3 parts of the epididymis and of the vas deferens, measurements were on spermatozoa. The 5 types of cell are illustrated in Plate 1. Total extinction and area were measured for riuclei of 15 to 30 cells of each type for each animal. The mean of these measurements was taken as the best estimate 


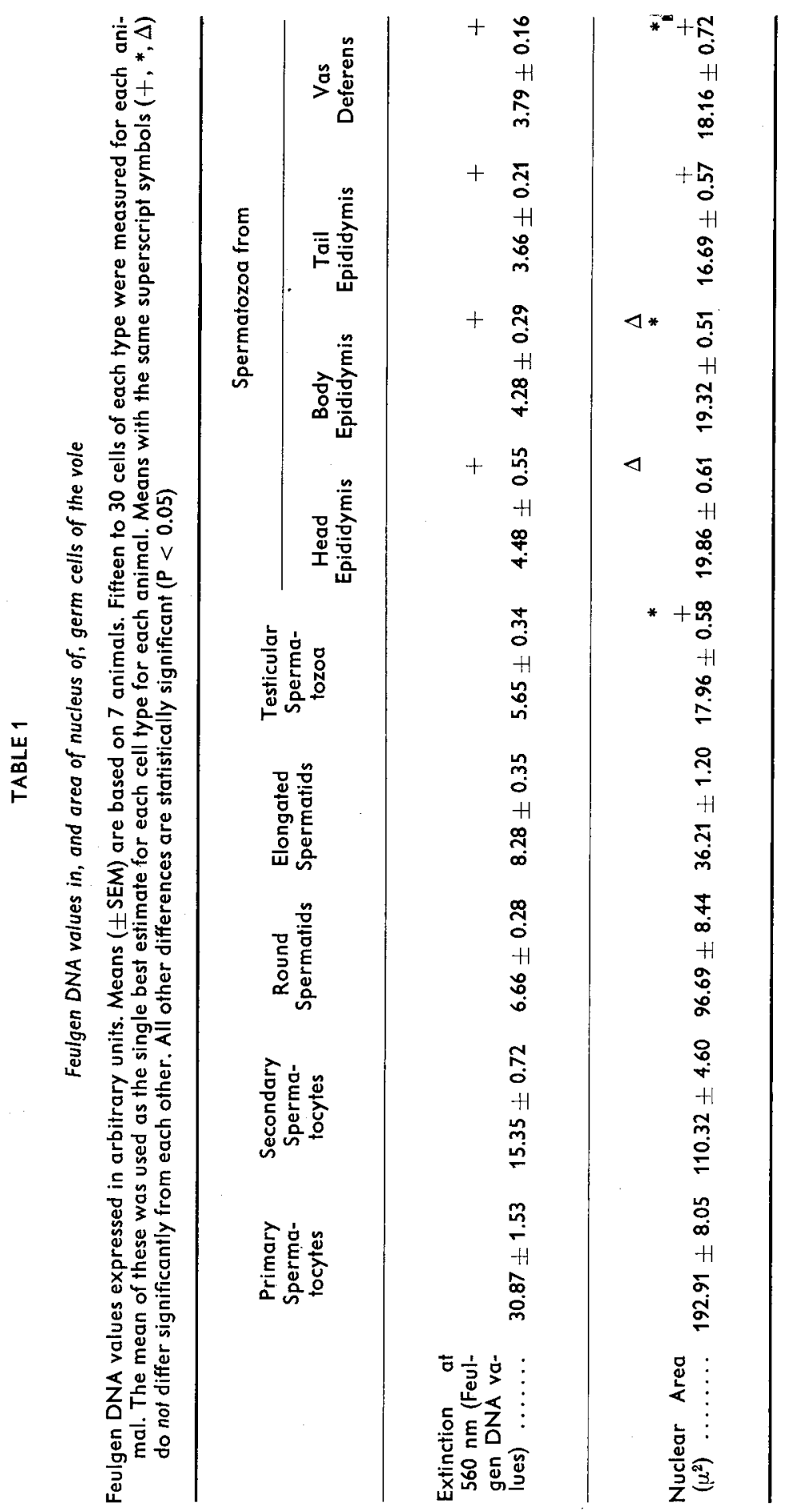


of these parameters for each type of germ cell for each animal, and used for the statistical analysis of the results, which are expressed as mean \pm SEM. Statistical significance of differences between means was examined by the $t$ test. Analysis of variance was carried out on total extinction values for haploid germ cells (round spermatids to spermatozoa from the vas deferens), and on nuclear area for spermatozoa from the testis through to the vas deferens (Bailey, 1961).

\section{Results.}

Within primary and secondary spermatocytes, and round spermatids of voles, the Feulgen DNA comprises two parts : a large, densely stained, circular patch within each nucleus, representing the large sex chromosomes typical of Microtus agrestis (Matthey, 1950) ; and more uniform, dispersed material, rather clearly organised as chromosomes in the primary spermatocytes (plate 1, figs. 1-3). On the other hand, in elongated spermatids and spermatozoa the Feulgen DNA is rather more accumulated in the postero-ventral part of the head than elsewhere (plate 1, figs. 4, 5).

Feulgen DNA values and nuclear area of the 5 types of germ cell are given in table 1. Primary spermatocytes have approximately 4 times, and secondary spermatocytes twice the Feulgen DNA value of round spermatids. The differences are highly significant statistically $(P<0.001)$. Analysis of variance of Feulgen DNA values of the haploid cells (round spermatids to spermatozoa from the vas deferens) shows that there is a highly significant change in the amount of Feulgen DNA $(P<0.001)$. The mean Feulgen DNA value for elongated spermatids is significantly augmented by about 24 p. 100 in comparison with that of the round spermatids $(P=0.01-0.001)$, and then diminishes significantly to testicular spermatozoa $(P<0.001)$. Testicular spermatozoa also have significantly lower mean Feulgen DNA values than round spermatids $(P=0.05-0.02)$. The decline in these mean values continues as spermatozoa pass down the epididymis to the vas deferens. Spermatozoa from the head, body and tail of the epididymis, and from the vas deferens, all have significantly smaller Feulgen DNA values than the testicular spermatozoa $(P=0.02-0.01 ; P=0.01-0.001$; $P<0.001 ; P<0.001$, respectively), and clearly than elongated and round spermatids. The Feulgen DNA values reach a minimum in the tail of the epididymis. The difference between mean values for tail and head of the epididymis is on the border line of statistical significance $(P=0.1-0.05)$. Mean values appear to stabilise from the tail of the epididymis to the vas deferens.

\section{PLATE 1}

Feulgen stained nuclei of germ cells from testis imprints of the vole (Microtus agrestis).

FIG. 1 : Primary spermatocyte; FIG. 2 : Secondary spermatocyte; FIG.3 : Round spermatids ; FIG 4 : Elongated spermatids; FIG.5 : Spermatozoa. Arrows point to the chromatin body comprising sex chromosomes. 

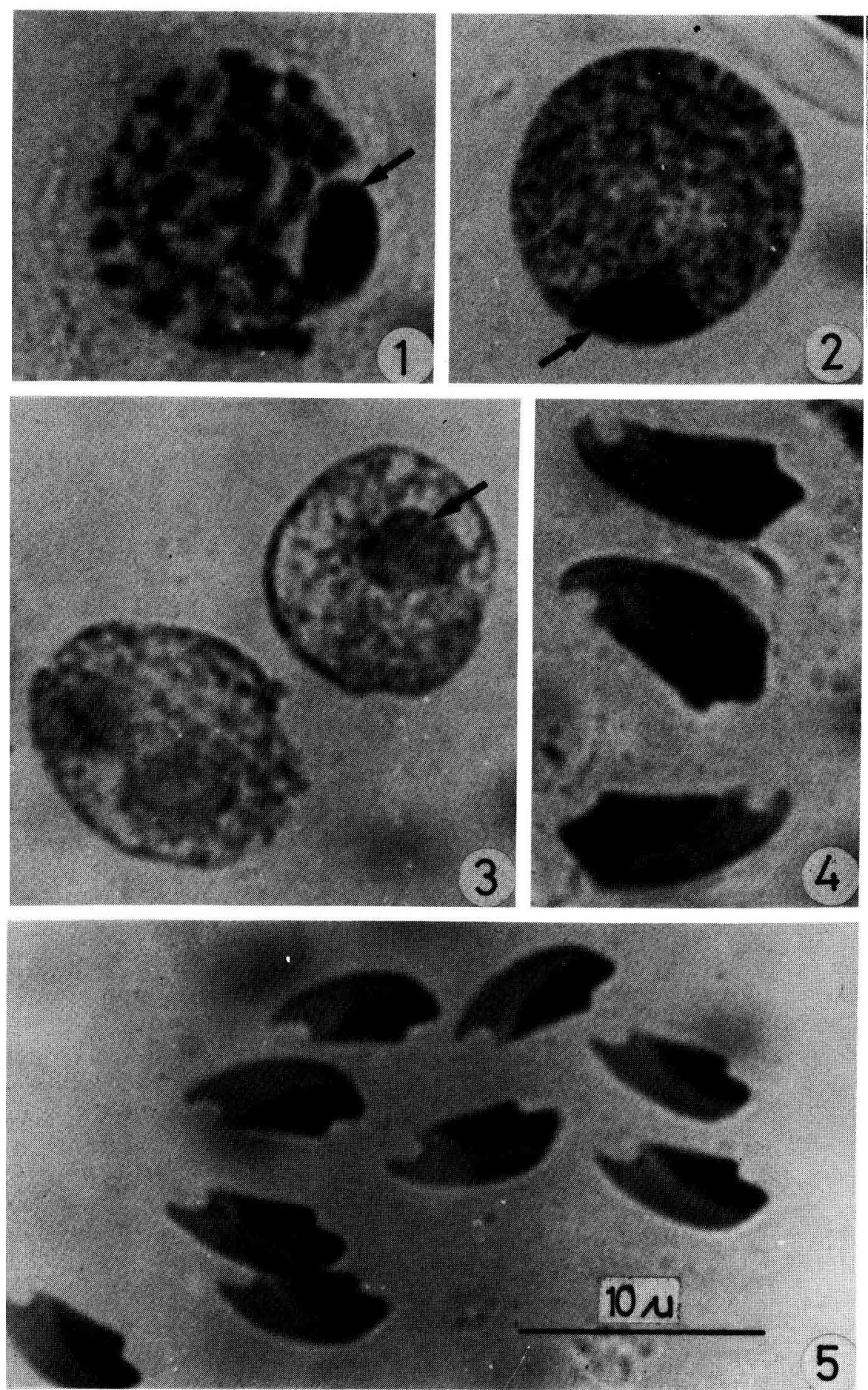
There is a highly significant decline in mean nuclear area from primary to secondary spermatocytes, from round to elongated spermatids, and from elongated spermatids to testicular spermatozoa $(P<0.001)$. Analysis of variance of nuclear area for spermatozoa from the testis through to the vas deferens shows significant alteration $(P=0.01-0.001)$. Comparing mean values for nuclear area of spermatozoa, there is a significant increase from the testis to the head of the epididymis $(P=0.05-0.02)$. The mean value for spermatozoa from the tail of the epididymis is significantly less than that for its body and head $(P=0.01-0.001, P<0.001$, respectively). The slight increase in mean nuclear area of vas deferens spermatozoa compared with that for spermatozoa from the tail of the epididymis, is on the border line of significance $(P=0.1-0.05)$. Mean nuclear area of vas deferens spermatozoa is significantly less than for that for spermatozoa from the head $(P=0.05-0.02)$, but not from that for spermatozod from the body of the epididymis. There is no statistically significant difference in nuclear area between spermatozoa from the testis, tail of the epididymis and the vas deferens.

\section{Discussion.}

The changes in Feulgen DNA values of male germ cells of the vole are essentially the same as those described already for the bull, the ram and the rabbit (Gledhill ef al., 1966 ; Bouters ef al., 1967a, b ; Courot et al., 1970 ; Esnault and Nicolle, 1976). The decline in Feulgen DNA from primary spermatocytes, through secondary spermatocytes to round spermatids corresponds with the accepted changes in ploidy which occur during these stages of germ cell maturation. The increased Feulgen DNA value seen in elongated spermatids has its counterpart in the bull and sheep, in which the increase is seen in elongating rather than elongated spermatids (Courot ef al., 1970). Assuming that the processes involved in spermatogenesis of the vole are similar to those in other species, the augmentation of the Feulgen DNA value in elongated spermatids could reflect enhanced staining of the deoxyribose by the leucofuchsin because of greater accessibility of the DNA (Sibatani, 1953 ; Noeske, 1971). This may be brought about through the loss of histones rich in lysine, before the accumulation of proteins specific to spermatozoa. In point of fact the loss of lysine in the ram occurs at the beginning of the phase of elongation of spermatids (Loir and Lanneau, 1978).

On the other hand the decline in staining of the nuclear material by the Feulgen reaction, which occurs as spermatozoa pass from the testis to the vas deferens, may be related to the state of condensation of the chromatin. Nuclear proteins are sulphated and develop disulphide bridges during the last phase of spermatogenesis (Loir 1972a, b, in the ram) and in epididymal maturation of spermatozoa (Marushige and Marushige, 1975, in the rat). Tight cross-linking of the proteins is associated with condensation of the chromatin (Calvin and Bedford, 1971, in the rat, rabbit and opossum). In the ram (Esnault, 1965 ; Esnault and Nicolle, 1976) and the bull (Gledhill et al., 1966) chromatin condensation is accompanied by a reduction in the Feulgen staining of the DNA. By contrast, decondensation of the chromatin through reduction of the disulphide groups with dithiothreitol, causes an increase in Feulgen DNA staining in the ejaculated spermatozoa of the ram (Esnault, 1973). Noeske (1971), in a cytophotometric study of the nuclei of bone marrow cells, showed that alteration in the 
functional state of the chromatin without modification in the amount of DNA present, affected the Feulgen reaction. Furthermore, the presence in the nucleus of spermatozoa of histones rich in arginine (Coelingh ef al., 1969 in the bull, Monfoort et al., 1973 in the boar, stallion and ram) is associated with a slight masking of the DNA (Mirsky and Silverman, 1972). The greater accumulation of Feulgen DNA in the postero-ventral part of the nucleus of spermatids and spermatozoa has been recognised already for the bull, ram and rat (Courot ef al., 1970).

Concomitant with part of the changes in amount of Feulgen DNA is a marked reduction in nuclear size, so that elongated spermatids have a nuclear area one sixth that of primary spermatocytes. There is an additional considerable reduction in nuclear size in the transformation from elongated spermatids to testicular spermatozoa. A slight, statistically significant, increase in nuclear area occurs as spermatozod pass to the head of the epididymis. This is followed by a significant decline in area as they move to the tail of the epididymis and the vas deferens. Slight decline has been recorded in nuclear area of bull and ram spermatozoa passing through the epididymis into an ejaculate (Gledhill, 1966 ; Esnault and Nicolle, unpublished observations).

Reçu en ovril 1979.

Accepté en aoot 1979.

Acknowledgments. - J. R. C. wishes sincerely to thank Dr. R. Ortavant, Chef du Département de Physiologie Animale (I. N. R. A., Nouzilly, France) for making a 6 month visit to his laboratory possible, the Wellcome Trust for a research travel grant, and Mrs. Judith Baker for technical assistance.

Résumé. La quantité d'ADN-Feulgen des spermatides rondes du campagnol agreste est environ le quart de celle des spermatocytes primaires. Ces modifications correspondent aux changements numériques des chromosomes pendant le développement des cellules germinales. Il y a entre autre une légère augmentation de la quantité d'ADN-Feulgen dans les spermatides allongées, puis une diminution régulière dans les spermatozoïdes du testicule, de l'épididyme et du canal déférent à un niveau inférieur à celui des spermatides rondes. En même temps la surface des noyaux diminue : celle des spermatozoïdes est le dixième de celle des spermatocytes primaires. La cause de cette augmentation et de cette diminution de la quantité d'ADN-Feulgen est probablement une modification d'affinité du désoxyribose pour la leucofuchsine. Celle-ci résulte peut-être des changements complexes physico-chimiques qui se produisent dans la chromatine et ailleurs dans le noyau ou la cellule lorsqu'ils acquièrent leur forme finale très spécialisée.

\section{References}

BAILEY N. T. J., 1961. Statisfical methods in biology. English Univ. Press, London, ix-200 pp.

BOUTERS R., ESNAULT C., SALISBURY G. W., ORTAVANT R., 1967a. Discrepancies in analysis of deoxyribonucleic acid in rabbit spermatozoa involving Feulgen staining (Feulgen DNA) and Ultraviolet light absorption (UV-DNA) measurements. J. Reprod. Fert., 14, 355-363.

BOUTERS R., ESNAULT C., ORTAVANT R., SALISBURY C. W., 1967b. Comparison of DNA revealed by Feulgen and by ultra-violet light in rabbit spermatozoa after storage in the male efferent ducts. Nature, 213, 181-182.

CALVIN H. I., BEDFPRD J. M., 1971. Formation of disulphide bonds in the nucleus and accessory structures of mammalian spermatozoa during maturation in the epididymis. J. Reprod. Fert., Supp. 13, 65-75. 
COELINGH J. P., ROZIJN T. H., MONFOORT C. H., 1969. Isolation and partial characterization of a basic protein from bovine sperm heads. Biochim. biophys. Acta, 188, 353-356.

COUROT M., HOCHEREAU-DE REVIERS M.-T., ORTAVANT R., 1970. Spermatogenesis. Chapter 6, 339-432. In JOHNSON A. D., GOMES W. R., VANDERMARK N. L., The Testis, Vol. 1. Acad. Press, New York and London.

ESNAULT C. 1965. Cited by Courol ef al., 1970.

ESNAULT C., 1973. Reactivation of the Feulgen reaction of ram spermatozoa by dithiothreitol. J. Reprod. Fert., 32, 153-157.

ESNAULT C., FAUTREZ F., ORTAVANT R., 1964. Evolution de la teneur en matériel ADN-Feulgen des cellules germinales de béliers soumis à différentes photopériodes. V Congr. int. Reprod. Artif. Insem. Ani., Trento, 419-424.

ESNAULT C., NICOLLE J. C., 1976. Evolution de l'ADN et des protéines nucléaires basiques au cours de la maturation des cellules germinales du bélier. Étude microspectrophotométrique. Ann. Histochim., 21, 189-197.

GLEDHILL B. L., 1966. Studies on the DNA content, dry mass and optical area of bull spermatozoa heads during epididymal maturation. Acto vet. scand., 7, 131-142.

GLEDHILL B. L., GLEDHILL M. P., RIGLER R., RINGERTZ N. R., 1966. Changes in deoxyribonucleoprotein. Exp. Cell Res., 41, 652-665.

GROCOCK C. A., CLARKE J. R., 1974. Photoperiodic control of testis activity in the vole (Microtus agrestis). J. Reprod. Fert., 39, 337-347.

GROCOCK C. A., CLARKE J. R., 1975. Spermatogenesis in mature and regressed testes of the vole (Microtus agrestis). J. Reprod. Fert., 43, 461-470.

GROCOCK C. A., CLARKE J. R., 1976. Duration of spermatogenesis in the vole (Microfus agrestis) and bank vole (Clethrionomys glareolus). J. Reprod. Fert., 47, 133-135.

LOIR M., 1972a. Métabolisme de l'acide ribonucléique et des protéines dans les spermatocytes ef les spermatides du bélier (Ovis aries). Il. Variation de l'incorporation et devenir de la ${ }^{3} \mathrm{H}$ lysine, de la ${ }^{3} \mathrm{H}$ arginine et de la ${ }^{35} \mathrm{~S}$ cystine. Ann. Biol. onim. Bioch. Biophys., 12, 411-429.

LOIR M., 1972b. Métabolisme de l'acide ribonucléique et des protéines dans les spermatocytes et les spermatides du bélier (Ovis aries). III. Étude cytochimique des transformations protéiques dans les vieilles spermatides. Ann. Biol. onim. Bioch. Biophys., 12, 531-544.

LOIR M., LANNEAU M., 1978. Transformation of ram spermatid chromatin. Exp. Cell Res., 115, 231243.

MARUSHIGE Y., MARUSHIGE K., 1975. Transformation of sperm histone during formation and maturation of rat spermatozoa. J. biol. Chem., 250, 39-45.

MATTHEY R., 1950. Les chromosomes sexuels géants de Microtus agrestis L., Cellule, 53, 163-184.

MIRSKY A. E., SILVERMAN B. 1972. Blocking by histones of accessibility to DNA in chromatin. Proc. nat. Acad. Sci. U.S.A., 69, 2115-2119.

MONFOORT C. H., SCHIPHOF R., ROZIJN T. H., STEYN-PARVÉ E. P., 1973. Amino acid composition and carboxyl-terminal structure of some basic chromosomal proteins of mammalian spermatozoa. Biochim. biophys. Acta, 322, 173-177.

NOESKE K., 1971. Discrepancies between cytophotometric Feulgen values and deoxyribonucleic acid content. J. Histochem. Cytochem., 19, 169-174.

SIBATANI A., 1953. Feulgen reaction and quantitative cytochemistry of desoxypentose nucleic acid. III. Effects of histone on the Feulgen reaction in vitro. J. Biochem., Tokyo, 40, 119-134. 